\title{
ARGENTINA IN CRISIS: SUPERHEROES IN ZENITRAM (2010) AND KRYPTONITA (2015)
}

\section{Vinodh Venkatesh (a)}

(a) Virginia Tech. Blacksburg, USA. Email: vinodhv[at]vt.edu

\begin{abstract}
While the study of superheroes has become a comprehensive field in itself, a focus on global superheroes has only recently begun to take shape. Vinodh Venkatesh's Capitán Latinoamérica: Superheroes in Cinema, Television, and Web Series (2020) furthers a comprehensive examination of the superhero in Latin American moving images from the late 1950s to the present day, covering contexts from Mexico to Chile. Missing from this study, however, is an examination of Argentine superheroes. The present essay fills this gap by addressing two films, Zenitram (2010) and Kryptonita (2015), that portray and critique Argentina and its relationship with neoliberalism in the 20th and 21st centuries. Both films move beyond the parameters of genre cinema by engaging salient issues extant in the cultural horizon of the country.
\end{abstract}

Keywords

Superhero; Argentina; Kryptonita; Zenitram; Latin America; Genre Cinema

This work is licensed under a $\underline{\text { Creative Commons «Attribution» } 4.0 \text { International }}$ License. 


\section{АРГЕНТИНА В КРИЗИСЕ: СУПЕРГЕРОИ В ТЕЛЕСЕРИАЛАХ ЗЕНИТРАМ (2010) И КРИПТОНИТА (2015)}

\section{Венкатеш Винод (a)}

(a) Политехнический университет Вирджинии. Блэксберг, США. Email: vinodhv[at]vt.edu

\section{Аннотация}

В то время как изучение супергероев само по себе стало всеобъемлющей областью, акцент на глобальных супергероях стал появляться только в последнее время. Работа Винода Венкатеша "Капитан Латинской Америки: Супергерои в кино, телевидении и веб-сериалах" (2020) дают представление о супергероях в Латинской Америке с конца 1950-х годов и по настоящее время, охватывая контексты от Мексики до Чили. Однако в этом исследовании не хватает изучения аргентинских супергероев. Настоящее эссе заполняет этот пробел, рассматривая два фильма, "Зенитрам" (2010) и "Криптонита" (2015), в которых изображается и критикуется Аргентина и ее связь с неолиберализмом в XX и XXI веках. Оба фильма выходят за рамки жанрового кинематографа, затрагивая актуальные вопросы, сохранившиеся в культурном ландшафте страны.

Ключевые слова

Супергерой; Аргентина; Криптонита; Зенитрам; Латинская америка; Жанр кинематографа

Это произведение доступно по лицензии Creative Commons «Attribution» («Атрибуция») 4.0 Всемирная 
While the study of superheroes has become a comprehensive field in itself, agglomerating scholars from political science, critical theory, and literary, film, and cultural studies (see, for example, the oeuvre of the University Press of Mississippi), a focus on global superheroes has only recently begun to take shape. Rayna Denison and Rachel Mizsei-Ward's Superheroes on World Screens (2015) is the first comprehensive study to tackle this important subsection of the superhero phenomenon in global cultural circuits. Yet what is quite surprising in this anthology is that over the course of 9 excellent essays that address issues of transculturation, transnational cinema, and the socio-cultural impact of local heroes, not a single superhero from Latin America is analyzed. Addressing this critical gap, Vinodh Venkatesh's Capitán Latinoamérica: Superheroes in Cinema, Television, and Web Series (2020) furthers a comprehensive examination of the superhero in Latin American moving images from the late 1950s to the present day, covering contexts from Mexico to Chile.

In broad strokes, Venkatesh argues that the contemporary Latin American superhero-across a spectrum of media outlets, platforms, and circulatory mechanisms-is a hybrid figure that integrates three distinct archetypes. These are: the US superhero (usually from the DC and Marvel catalogs); the Mexican wrestler-as-superhero who saw its zenith in the 1960s and 70s (see famed luchadors such as El Santo and Blue Demon); and El Chapulín Colorado, a parodic superhero that appeared in a homonym television show from 1973-1979 (and afterwards in syndication) that was ubiquitous across the Spanish-speaking world. The contemporary Latin American superhero is, importantly, deeply rooted in their national contexts, playing out and reflecting on significant ethical, political, social, and economic issues. They serve as a conduit for particular local issues that already dominate the cultural horizon of their respective national contexts. Perhaps most importantly, the Latin American superhero is not a conservative Trojan Horse that while at face-value fights crime, only really maintains the status quo (see the principal Anglo narratives). Instead superheroes such as El Man (Colombia), Chinche Man (Honduras), Capitán Centroamérica (El Salvador), and Mirageman (Chile) stand up for the layperson against systems of power, injustice, and the Law. El Man, for example, sets up a local market based on barter to counteract the nefarious expansion of a multinational company in downtown Bogotá, while the metonymic plot of Mirageman (2007) critiques the transition from the dictatorship of Augusto Pinochet to the current democracy in Chile, to some extent almost foreshadowing the current crisis in the country. 
Missing from Capitán Latinoamérica, however, is a thorough examination of contemporary superheroes from Argentina, an important absence given the country's stature in the region both in commercial and critical cinema circles ${ }^{1}$. The following pages address this omission by studying two argentine iterations of the genre, Zenitram (2010) and Kryptonita (2015). In doing so, I argue that these superheroes maintain the overall ethos of the contemporary Latin American superhero, while addressing the particularities of the Argentine context, namely the country's oscillating relationship with the neoliberal turn in Latin America, and the socioeconomic impact of the 2001 financial crisis on everyday lives. In doing so, these popular genre films enter into dialogue with some of the most salient issues identified in the study of contemporary Argentine film, thus moving beyond the ethical and thematic parameters often used to cloister genre film.

Argentina has a deep cultural history with the figure of the superhero. Indeed, the earliest print character that could be considered a superhero predates the debut of Jerry Siegel and Joe Shuster's Superman in Action Comics \#1 (April 18, 1938). I am here referring to the popular Patoruzú comics, which made their debut in 1928. He is a Tehuelche cacique who fights thieves and other petty criminals with his superhuman strength and speed. Other characters to note include Sónoman (1966) and Sherlock Time (1958), while there is also a strong tradition of the layman who-due to some extraordinary circumstance-becomes a hero that saves the nation ${ }^{2}$.

Adaptations of these local heroes to the moving image is another thread to follow. Here we can first highlight Patoruzú's appearance in the animated short Upa en apuros (1942). Decades later, the female superheroes from Cybersix (first published as comics in the early 1990s) were made into a live-action series in 1995, and then a multinational animated series in 1999. The protagonist, Cyber-6, originates as a Nazi experiment gone wrong, forced to adopt a male persona by day, and face the threat posed by the Nazi doctor who created her (Dr. Von Reichter) by night. The live-action series ran for eight episodes, but the animated series was more

1 Venkatesh provides a very brief overview of these characters in the concluding chapter of the book. Argentina, Mexico, and Brazil are typically considered to be the biggest producers of cinema in Latin America. Critical interest in Argentine cinema was resurrected in the late 1990s and early 2000s, in what scholars such as Gonzalo Aguilar and Jens Andermann have called New Argentine Cinema, through the films of such directors as Pablo Trapero, Martín Rejtman, Lucrecia Martel, and Adrián Caetano amongst others. In addition to several other over-arching characteristics, Aguilar furthers that these films are defined by an "avoidance of allegorical stories" (16), and that they

"insist upon the literal and tend to frustrate the possibility of an allegorical reading" (16-17).

2 We can include in this category such comics as Rolo, el marciano adoptivo (1957), while the nowcanonical El Eternauta (1957) portends a more somber fate for the nation. 
successful, as it appealed to a wider audience due to its manga aesthetic and science fiction themes (though the adult themes of the Nazi past and sex scenes were omitted in the interest of attracting young viewers).

These examples establish the presence of the autochthonous superhero in both print and moving-image media in the Argentine cultural horizon during the 20th century, but this presence did not translate into realm of feature-length productions. In fact, it is only in 2010 that we see the first Argentine superhero film, that is, Luis Barone's Zenitram. The timeline is unsurprising, since genre cinema is a relatively new trend in the country. In studying the horror genre, Jonathan Risner provides a broader observation:

Over the past fifteen or twenty years Argentina has emerged as a producer of genre films that diverge from more established national film genres, such as melodrama, detective cinema, auteur cinema, and documentary. Screwball comedies, animation, martial arts, horror, trash cinema, and science fiction all compose a loosely conceived "wave" of contemporary filmmaking that is periodically dubbed "Cine Independiente Fantástico Argentino" ("Argentine Independent Fantastic Cinema") and "Nueva Ola de Cine de Género Argentino" ("New Wave of Argentine Genre Cinema"), among other monikers [...] Other higher-budgeted commercial films made with the support of INCAA [...] nevertheless are couched as part of a larger surge of genre cinema that unabashedly traffics in and reworks transnationally established genres with a stated objective of filmmakers almost invariably being to "entertain" the audience. (xvi)

We can thus couch the production of Zenitram within this "Nueva Ola" that Risner identifies as taking shape in a parallel fashion to a more established cinema that has come to dominate academic discussions of an Argentine Cinema ${ }^{1}$.

Juan Minujín (as Rubén) and Verónica Sánchez (as Laura) star in Zenitram, an Argentine-Spanish co-production that addresses issues permeating contemporary Argentina such as the proliferation of the neoliberal state, the privatization of public goods, an impending climate disaster, and the disenfranchisement of the populace as soulless multinationals commoditize natural resources ${ }^{2}$. While the narrative takes place in the year 2025, the audience can intuit that the diegetic dystopia is not so farfetched given the trajectory of the country in the first decade of the 21stcentury (it is indeed less outlandish as I watch the film in 2020). The film follows in the thematic footsteps of several earlier films from the 90s and

1 Especially the auteur and slow cinema that characterizes New Argentine Cinema and its descendants.

2 Critics such as Joanna Page identify the economic collapse and crisis of 2001 as being a defining factor in the cinematic production of the country. 
2000s (albeit in the register of the superhero), following Joanna Page's assertion that "money emerges as the universal theme of contemporary Argentine cinema" (5).

Page (in addition to several other critics) juxtapose the production and themes of contemporary Argentine cinema around the crisis of 2001, which was really a protracted economic fallout between 1998-2002 where the country entered a freefall after recovering for a few years from another economic depression (1974-1990). The 2001 event was predicated by: the alignment of the national economy with the neoliberal turn in Latin America by President Menem; the pegging of the austral to the US dollar; and significant macroeconomic fissures that deepened as the government was unable to cope with rising debt, unemployment, and stagflation. All this came to a head in December 2001, when Argentines took to the streets in massive protests that turned violent as soon as they were met with resistance from the police. As a result, films produced at the turn of the century tend to focus on multiple aspects of the politico-economic rollercoaster that shell-shocked the social telos of the country ${ }^{1}$.

The very first image sutures the film to both this nation in crisis, and a print tradition (though in this case, there is no original Zenitram comic, as the film is based on a short story by Juan Sasturain), as we see the hands of an artist draw a storyworld and a voice-over relates that the city of Buenos Aires is reeling from a drought created by climate change, and that the capitalist appropriation and exploitation of water sources by large multinationals has led to widespread suffering and economic depression ${ }^{2}$. While at first glance the opening may seem banal, a closer examination aligns the film with what Dru Jeffries calls "comic book film style," or "the results of an intermedial relationship between comics and film, whereby the latter medium appropriates and transforms certain of the formal attributes unique to the former as a means of stylization" (2). Jeffries furthers that "comic book film style can be described as a set of self-reflexive gestures in which the different representational abilities of comics and film are put on simultaneous display in a cinematic work" (3). In comic book film style, "the storyworld is filtered through both comics and cinema before it reaches the viewer's perception, resulting in self-consciously stylized or 'hypermediated' representations, as opposed to a logic of transparency or 'immediacy' [...] it is something that is imposed upon the diegesis, not something that emerges from it" (3, emphasis in the original). The opening images thus associate the film with a print tradition,

1 The political reverberations were immense, as the country had 5 presidents over the span of 2 weeks (Page 1).

2 There are a growing number of Argentine films and media focused on the current state of the environmental crisis. See Caña Jiménez. 
thus linking Zenitram to a transnational (superhero) genealogy rooted in the conventions and characters of the genre. The stylized aesthetics of the initial scene are not altogether different than the opening Marvel Studios title in every film from their cinematic universe (MCU), which explicitly places the films in a direct reference to their almost 80 years of print culture ${ }^{1}$.

The imposition of the comic style, that is, the request made of the viewer to filter the diegesis not only through the contemporaneity of the narrative world of the diegesis but also through the textuality of the comic, lays out for the spectator a pro-filmic map. As Jeffries understands it, "comic book film style is nondiegetic, but it influences and conditions our access to the diegetic world on display in the film" (3). It directs us to Tom Conley's idea "that in its first shots a film establishes a geography with which every spectator is asked to contend" (2). In other words, the opening aesthetics of Zenitram lay bare a multi-scaffolded relationship between the viewer and the image, encouraging a self-reflexive hermeneutics that moves beyond the simple gesture of "entertainment" that tends to define genre cinema. The audience is explicitly asked to read and analyze the film within the trope of crisis (that many in the audience undoubtedly lived through) while otherwise being entertained, marveling at the special effects and the other clichés of the superhero genre. In other words, we should read allegorically, understanding that the chronological future portrayed in the film is not a manifestation of fantasy, but rather very much a commentary of the present ${ }^{2}$.

The voice-over's dire message takes an optimistic route when we are told that hope springs from the rubble of a civilization in decay, from "the middle of fucking nowhere" ("el culo del mundo"), "a kid ... another moron ... came to save us" ("un pibe ... un boludo más ... nos vino a salvar"). The cartoon aesthetic gives way to live-action as we see Rubén Martínez, a skinny young man from a marginal neighborhood of Buenos Aires, working as a trash collector. His route is interrupted when he skirmishes with a group of homeless and downtrodden denizens that scavenge the trash he is tasked with collecting. He thus realizes that what he considers trash is recycled and repurposed by this invisible underclass; such a realization has its price, as his supervisor fires him for not stopping the "looting" of trash. The lexicon used here is imperative: even what would normally be considered waste is now monetized, a commodity owned by the

1 This genealogy is transformed in later films of the MCU as images from earlier films substitute the print avatars.

2 Angela Ndalianis observes that superhero films are so popular in the current global mediascape because of their "connection to major contemporary events [...] As we might expect, superhero narratives seem to be inextricably linked to the realities of social and political life" (1). 
waste company. Importantly, the opening scene places Zenitram within the thematic (though not aesthetic) tenor of contemporary critically-acclaimed films such as Pizza, birra, faso (1998, Bruno Stagnaro and Adrián Caetano) and Mundo Grúa (2002, Pablo Trapero) that focused on the mounting poverty and crime extant in Buenos Aires. In these films, the city is "a fractured, heterogenous space with internal divisions of its own," that dismantle the myth of the "exceptionality of Bueno Aires as a cultured, First World capital set apart from the troubles of the rest of the country" (Page 111).

Out of a job, Rubén proceeds to a public bathroom where-in a very quick origin moment- a mysterious stranger informs him that he is a superhero. He simply has to say the name "Zenitram" while clutching his testicles to activate his powers, which include the ability to fly and superhuman strength. This quick opening sequence lacks some of the gravitas, fantasy, or tragedy that typically characterizes the origin of the superhero. Writing on the conventions of the genre, Robin Rosenberg observes that "a fictional origin story begins by telling us something about a character [...] before the character is transformed. Then an origin story tells us about the pivotal events that initiate the transformation. The significant events usually involve adversity of some kind" $(2)^{1}$. At first glance, there are no such conditions in this scene; but if we expand the narrative trail to the previous scene, then we can understand that the character's origin moment is triggered by his firing after allowing the "looting" of the trash. In other words, the superhero in Zenitram is born from the socioeconomic collapse of a Buenos Aires facing an imminent ecological disaster.

While the superhero will mimic several characteristics of hegemonic US archetypes (such as his sartorial choices and his ability to fly), the principal intertext for reading Zenitram is the iconic El Chapulín Colorado, whose yellow leotard over a skinny frame contrasts with the hypermasculinity of the muscled bodies that are paraded in the DC and Marvel universes. Chapulín is middle aged, does not have defined abdominal muscles, and saves the day often by accident (and cowardice) and not by some sort of heroic, altruistic act. Rubén clutching at his testicles to activate his powers draws our attention to the exaggerated, almost comical machismo that the character needs to engage in to become a superhero ${ }^{2}$. The recourse to parody as a mode (within the archetype of the superhero)

1 Rosenberg adds that the "origin story thus describes two types of transformation: (1) the transformation of the protagonist into a hero, if he or she wasn't beforehand; (2) the transformation viz. special powers, in which the character develops, discovers, masters, and/or decides how to use special powers over the course of the origin story" (4).

2 Other examples of parody include scenes when he flies with Laura. She always vomits upon landing as the extreme G-forces of flying naturally provoke nausea-a fact that is glossed over in the traditional superhero narrative. 
emphasizes the protagonist's disenfranchisement along several hierarchies: in the economic sense, as he is first poorly paid, and then unemployed; and in the social sense, as his lack of sex appeal and social capital excise him from the arenas of power dominated by wealthy businessmen and politicians that comprise the overclass of the dystopic city.

In this regard, we may read Rubén and Zenitram as another entry in what Carolina Rocha has identified as a corpus of Argentine films from the 1990s onwards that feature "distressing narratives about men's disempowerment" (1). Framed within the neoliberal turn and the events of 2001, Rocha argues that "because middle-class masculinities were traditionally associated with the State-both in Argentina and elsewhere-the cinematic representation of middle-class masculinities in crisis is related to the inception of neoliberalism in Argentina, a change that had significantly modified the Argentine State" (1), and that there is a "strong correlation between the demise of a certain type of State and the middle-class masculinities associated with it" (1). Rocha, furthermore, provides a tripartite division of these films into: narratives that "anticipate the breakdown of the state;" "films in which the figure of the father is no longer central;" and films that explore "the downfall of the State" (17-18). While Zenitram most obviously follows the latter category, as the State no longer is an abode for the citizen, we may also find points of contact with the middle idea, that is, with films where the father figure (as metonym of the State) is no longer central. In this notion, the personal is linked to the communal, as the nuclear family is metonymic of the national family. It is a category especially propitious for the superhero genre, as origin stories are:

most commonly organized around father figures, Oedipal trajectories, and patriarchal genealogies. Superheroes in these films undergo an obsessive quest for re-establishing stable points of origin in semi-mythical father figures associated with omnipotent forms of power and omniscient forms of knowledge. This motif points towards a reactionary desire for stable signification in an age of increasing instability [and] ephemerality. (HasslerForest 24)

Rubén, in fact, lives alone with his mother, and the only father figure he has is Mingo Arroyo (Laura's father), an eccentric neighbor who claims to have the blueprints to create a machine to end the drought. But Mingo does not play a role in Zenitram's origin story, nor does the protagonist attempt to find some sort of stability in the character-if anything, we may extrapolate the lack of the father in Rubén's nuclear family to the lack of the State overseeing the national family. This would explain the 
montage of scenes leading up to the origin moment in the bathroom, a moment I contend is crafted by the images of despair in the streets and not within the visual unit of the bathroom scene.

The dismemberment and downfall of the State occurs at the hands of the principal antagonist, a foreign multinational called WaterWay that is headed by Daniel Durbán, whose prominent Peninsular Spanish accent evokes the economic reconquista or reconquest of Latin America in the 1990s by Spanish companies and financial institutions. Not only does he steal the city's water, but he also makes moves on Rubén's love interest. Zenitram thus confronts WaterWay on two fronts: first, he seeks to free the population from the economic shackles of the conqueror; and second, to vanquish the Spanish suitor vis-à-vis Laura.

While at face value it may seem that Zenitram's principal conflict resides with the foreign company, a deeper analysis demonstrates that what is truly at stake is the local, communal, and the State (or whatever may be left of it). This meditation on a national self or character is played out over various scenes. In one example, Zenitram laments that "this country destroys its heroes" ("este país destruye a sus héroes"), leading him to want to emigrate to Miami ${ }^{1}$. In several other moments, he comes under fire from the press and popular opinion even after having engaged in an act of heroism.

A second critique surfaces when the superhero is incorporated into the machinery of the State. Unlike archetypes such as Batman-who operates outside the Law-and Superman-who is a key ally of the Law-, Zenitram is given the unceremonious position of Minister of Special Affairs. While on paper his charge seems to be of utmost importance, we see instead the inefficiency and absurdity of Argentine bureaucracy as his job is solely characterized by mountains upon mountains of paperwork. Whatever good the superhero can do through his superpowers are negated by the mundanity of red tape. Also of note are the political overtones of the various conversations maintained between Rubén, Laura, and Durbán as the plot evolves: they are balanced in their critique of rightwing and leftwing governments and policies, leaving no stone unturned. The criticism of the former is understandable, given the debacle of the 1990s that culminated in the riots of 2001; the reproach of the latter, however, is thought-provoking as the film was made during the government of Cristina Fernández de Kirchner (2007-2015), which was part of the Latin American "pink tide" or a movement towards leftist policies and a rejection of neoliberalism. Fernández de Kirchner, we would find out towards

1 Indeed, anybody who follows the Argentine national football team will know that this statement is very much true. 
the end of her presidency, was no saint, as she was embroiled in several corruption and fraud scandals-the critique of the politics at large, then, in Zenitram foreshadows and is apropos of a broader disillusionment with the State (regardless of its political hue).

As the film proceeds with kitschy special effects and comic relief, Durbán becomes a de facto dictator, and engineers the public downfall of the superhero, who he views as a challenger not only to his stake as head of the State, but also in terms of his designs on Laura ${ }^{1}$. As Zenitram is left out of commission, the mantel of justice is taken over by Laura who leads an urban guerrilla movement called Círculo Rojo that explicitly evokes the guerrilla forces during the Argentine Dirty War. Exiled to Miami, Zenitram undergoes a bout of soul-searching before realizing that his place is back in Buenos Aires and at the helm of the resistance to the government, which is now conflated with WaterWay. Politics and corporate interests are one and the same in this diegetic future. When Zenitram returns, he joins forces with the guerrilleros to take down Durbán, WaterWay, and a Cuban-American superhero who comes to Buenos Aires to protect the interests of the dictatorship (no doubt a reference to US interventionism in the region throughout the twentieth century and beyond).

In the climax, Zenitram and Círculo defeat Durbán, though the superhero pays the ultimate price by sacrificing himself to fix the ecosystem and bring about an unceasing rain to end the drought (which, as the voice-over indicates, creates a whole other slew of problems in the future). Importantly, when the superhero is questioned for joining the guerrillas and fighting against the government and military, he retorts that the rule of law only applies in the North, where superheroes are, ironically, not needed. Herein we see the film's principal addition to the Latin American superhero archive, as the character explicates the conservative nature of the archetypal superhero while gesturing towards the revolutionary possibilities of a local iteration ${ }^{2}$.

In closing, Zenitram beckons the viewer to reimagine the nation in a moment (and future) of crisis, suggesting a political engagement that surpasses the ennui and disenchantment with both sides of the political spectrum that have dug the country deeper into financial and political ruin. In doing so, the film is aligned with Page's observation that recent Argentine

1 The villain here follows Peter Coogan's description of the villain as "enemy commander" (61). Coogan argues that there are five types of villains in superhero narratives, namely "the monster, [...], the mad scientist, the criminal mastermind, and the inverted-superhero supervillain" (61). He furthers that these types are "non-exclusive" (61), and that villains can actually be a combination of these broader categories.

2 The local superhero follows Marc DiPaolo's description of the "anti-establishment narrative," where "the superhero stands in opposition to an evil governmental, corporate, or aristocratic villain" (12). DiPaolo further categorizes superhero narratives as "establishment" and "colonial" (12). 
cinema demonstrates a "critical focus on the nation," though the "nation is not associated here with the state but is most often invoked in criticism of a state in cahoots with global neoliberalism, which has sold off the country's assets and burdened it with intolerable levels of debt" (6, emphasis in the original).

This same focus is at the core of Nicanor Loreti's award-winning 2015 homonym adaptation of Leonardo Oyola's novel Kryptonita (2011). Based on the DC Comics model of Elseworlds (where local adaptations of archetypal superheroes and narratives are permitted), the film situates the well-known characters of the Justice League to a Buenos Aires ransacked by neoliberal policies. Each character is reborn as a local hero: Nafta Súper is Superman; El Federico is Batman; Faisán plays the Green Lantern; Ráfaga has the speed of the Flash; Cuñatai Güirá is a Guaraní Hawkgirl; and Lady Di is a trans Wonder Woman. While there are some vestigial traits and sartorial cues of the original characters, Loreti's Justice League is a grittier take on crime and social decay.

The narrative takes place over a single night in a hospital located in a marginal neighborhood of the city. A drug-addicted doctor who works the night shift to make ends meet is met by the Nafta Súper gang who-while escaping from the corrupt local police-seek emergency care for their injured leader. Loreti's film favors deep, introspective dialogues and monologues over the fast-paced action sequences see in Zenitram, resulting in a film that may be slow for some viewers. Indeed, Risner calls the film a "superhero spoof" (xvi) and "a skewering of the superhero genre" (19). I disagree with this characterization as a spoof would suggest some sort of humor or comic effect, or at best, a self-reflexivity vis-à-vis the genre. This is not the case with the film, as what is of central interest is the state of affairs in which the plot takes place. What I am trying to indicate here is that the superheroes and their intertextual reference to the DC Universe is ancillary; the real protagonist is the doctor who fights the odds to save the patient.

Indeed, the entire film revolves around his struggle to cure Nafta Súper, as he staves off urges to consume drugs and makes do with the limited resources at his disposal. The hospital is like many others in the neoliberal era that were eviscerated by austerity measures and a broader privatization of public goods. This particular hospital in a working-class neighborhood lacks staff, medicine, and basic supplies to cater to its underprivileged population. The film, like the issues at stake in the origin moment of Zenitram, focuses on the socioeconomic reality of the economically disadvantaged and politically disenfranchised laity. The fact that the superheroes never engage in super heroic acts or fight scenes supports 
this reading, as their actions and dialogue instead are always in relation to the doctor. The film, furthermore, gestures towards a centripetal drive through a final long shot that zooms out from the hospital and neighborhood, that is, we are to extrapolate the events and conditions of the diegetic setting (the hospital) to the broader city that now comes into focus. The final image thus spatially moves the viewer from the closed, dark spaces of the hospital towards society at large, following Hassler-Forest's claim that the superhero genre is "inextricably interwoven with the landscape and architecture of the modern city" (113).

Kryptonita was successful at the local box office, so much so that the producers embarked on an eight-episode television series called Nafta Súper, that premiered in 2016, and is now available for free through the producer's website (naftasuper.spacego.tv). The series takes off from the events of the film, as the superheroes now have to fight off the police and a new drug gang seeking inroads in the La Matanza neighborhood of the city. The television series, unlike the feature-length film, does have elaborate action sequences and CGI-inflected superpowers, thus aligning it with similar productions by Marvel and DC for TV audiences. Like the film, Nafta Súper is not a spoof, but rather a serious engagement with the superhero genre, albeit as it may be reimagined for the realities of the Latin America in the 21st century. That being said, the film lacks the narrative depth of Zenitram, and perhaps would have been better adapted in the run-time of a short film.

All in all, Zenitram and Kryptonita provide a cogent and thought-provoking critique of the episteme of politico-economic crisis that has come to characterize depictions of the national in recent Argentine cinematic production. By mobilizing these themes through the superhero genre, these films both successfully bring to a broader audience the most palpable issues facing the national body in the current moment, and rework the genre itself, highlighting fresh hermeneutic nuances and possibilities for engagement.

\section{References}

Aguilar, G. (2008). Other Worlds: New Argentine Film. Trans. Sarah Ann Wells. New York: Palgrave Macmillan.

Caña Jiménez, M.C. (2017). Violencia, necropolítica y capitalocene en Cromo [Violence, necropolitical and capitalocene in Cromo]. Revista Canadiense de Estudios Hispánicos [Canadian Fournal of Hispanic Studies], 42 (1), 1-23. (in Spanish)

Conley, T. Cartographic Cinema. (2007). Minneapolis: U of Minnesota P. 
Coogan, P. (2006). Superhero: The Secret Origin of a Genre. Austin: MonkeyBrain.

Denison, R., \& R. Mizsei-Ward, eds. (2015). Superheroes on World Screens. UP of Mississippi.

DiPaolo, M. (2011). War, Politics and Superheroes: Ethics and Propaganda in Comics and Film. Jefferson: McFarland.

Hassler-Forest, D. (2012). Capitalist Superheroes: Caped Crusaders in the Neoliberal Age. Winchester: Zero.

Jeffries, D. (2017). Comic Book Film Style: Cinema at 24 Panels Per Second. Austin: U of Texas $\mathrm{P}$

Ndalianis, A. (2007). Do We Need Another Hero? In W. Haslem, A. Ndalianis, and C. Mackie (Eds.). Super/Heroes. From Hercules to Superman (pp. 1-8). Washington: New Academia.

Page, J. (2009). Crisis and Capitalism in Contemporary Argentine Cinema. Durham: Duke UP.

Risner, J. (2019). Blood Circuits: Contemporary Argentine Horror Cinema. Albany: SUNY $\mathrm{P}$.

Rocha, C. (2012). Masculinities in Contemporary Argentine Popular Cinema. New York: Palgrave Macmillan.

Rosenberg, R. (2013). Superhero Origins: What Makes Superheroes Tick and Why We Care. CreateSpace.

Venkatesh, V. (2020). Capitán Latinoamérica: Superheroes in Cinema, Television, and Web Series. Albany: SUNY P.

\section{Список литературы}

Aguilar, G. (2008). Other Worlds: New Argentine Film. Trans. Sarah Ann Wells. New York: Palgrave Macmillan.

Caña Jiménez, M.C. (2017). Violencia, necropolítica y capitalocene en Cromo [Violence, necropolitical and capitalocene in Cromo]. Revista Canadiense de Estudios Hispánicos [Canadian Journal of Hispanic Studies], 42 (1), 1-23. (in Spanish)

Conley, T. Cartographic Cinema. (2007). Minneapolis: U of Minnesota P.

Coogan, P. (2006). Superhero: The Secret Origin of a Genre. Austin: MonkeyBrain.

Denison, R., \& R. Mizsei-Ward, eds. (2015). Superheroes on World Screens. UP of Mississippi.

DiPaolo, M. (2011). War, Politics and Superheroes: Ethics and Propaganda in Comics and Film. Jefferson: McFarland.

Hassler-Forest, D. (2012). Capitalist Superheroes: Caped Crusaders in the Neoliberal Age. Winchester: Zero. 
Jeffries, D. (2017). Comic Book Film Style: Cinema at 24 Panels Per Second. Austin: U of Texas P.

Ndalianis, A. (2007). Do We Need Another Hero? In W. Haslem, A. Ndalianis, and C. Mackie (Eds.). Super/Heroes. From Hercules to Superman (pp. 1-8). Washington: New Academia.

Page, J. (2009). Crisis and Capitalism in Contemporary Argentine Cinema. Durham: Duke UP.

Risner, J. (2019). Blood Circuits: Contemporary Argentine Horror Cinema. Albany: SUNY $\mathrm{P}$.

Rocha, C. (2012). Masculinities in Contemporary Argentine Popular Cinema. New York: Palgrave Macmillan.

Rosenberg, R. (2013). Superhero Origins: What Makes Superheroes Tick and Why We Care. CreateSpace.

Venkatesh, V. (2020). Capitán Latinoamérica: Superheroes in Cinema, Television, and Web Series. Albany: SUNY P. 